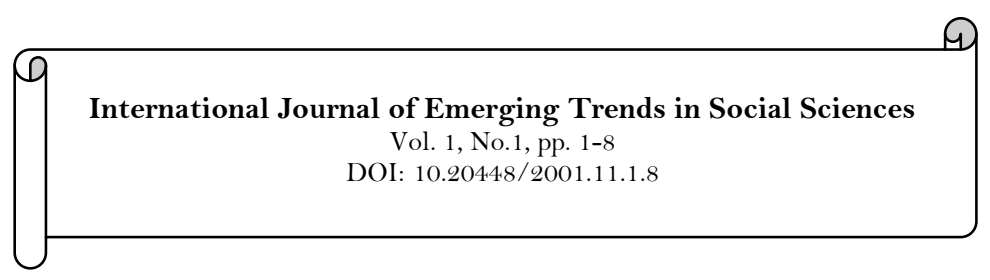

\title{
Disarmament, Demobilization and Reintegration (DDR) in Rwanda, 1997-2008: A Desk Exegesis and Agenda for Praxis
}

\author{
Okoli, Al Chukwuma ${ }^{1}$ \\ ${ }^{1}$ Department of Political Science, Federal University Lafia, Nigeria.
}

\begin{tabular}{l|l}
\multicolumn{1}{|c}{ Abstract } & \\
This paper examines the Rwandan experience of Disarmament, & Keywords: \\
Demobilization and Reintegration (DDR) from 1997 to 2008, with a & Demobilization \\
view to x-raying the nature, pattern, principles, and legacies of DDR & Disarmament \\
in that context, in addition to setting agenda for the practice of DDR & DDR \\
elsewhere in Africa. By way of a desk exegesis, the paper posits that & Reintegration \\
DDR was significantly successful given the fact that it led to & \\
successful demobilisation and reintegration of a large number of ex- & \\
combatants who participated in the Rwanda crisis. The paper notes, & Licensed: \\
however that the Rwanda DDR failed to a large extent in disarming & Creative Commons Attribution \\
and demobilizing many of the ex-armed groups operating in the & 4.o License. \\
country and its proximate region. In the light of the limited success & \\
of the Rwandan DDR efforts, it is therefore recommended that future & Publisher: \\
DDR programmes in Africa should be holistic and pragmatic enough \\
to address the concerns of DDR within the formal military sector as \\
well as frontiers of militia formations. This entails considering DDR
\end{tabular}

\section{Introduction}

State-building in post conflict situations is an onerous process that involves mitigation of multiple development and security challenges. The challenges include the task of reconstruction, rehabilitation, reconciliation and peace-building. A crucial aspect of this process is the imperative of demilitarizing the civil population in an attempt to ensure sustainable peace and stability (Takeuchi, 2011).

Demilitarizing the civil population in the aftermath of a violent conflict is a strategic process involving a conscious effort to disarm, demobilize and reintegrate the combatant elements of the society into the mainstream of civilian life. The essence of the process is to pragmatically dismantle the existing abusive military structures with a view to forestall the possibility of violent backlashes or a recrudescence of military violence (Okoli, 2015). The need to achieve a sustainable peace-building in post conflict states have led to the institutionalization of DDR (Disarmament, Demobilization and Reintegration) as a veritable state-building and security sector reform strategy.

According to Social Development Department (2009) DDR refers to "a process that contributes to security and stability by disarming combatants, removing them from military structures, and socially and economically integrating them into society". Over the years, various patterns of DDR programme have been implemented across the world, with Africa taking the lion's share (Carames \& Sanz, 2009); see also Table 6 -the appendix). In Africa, DDR has been implemented in Rwanda, Congo DR, Sierra-Leone, Liberia, Angola, Nigeria (Niger-Delta), Sudan, Cote d'Ivoire and Burundi, with varying degrees of success (Banholzer, 2004). This paper is concerned with the review of DDR in Rwanda with the intent to underscoring its legacies and constraints, as well as pointing out possible lessons for the practice in Africa. The remainder of the paper is structured along the following themes: overview of the Rwandan crisis; the Rwandan DDR experience; peculiarities and legacies of the Rwandan model of DDR; conclusion and recommendation.

\section{Conceptualizing and Operationalizing DDR}

The acronym 'DDR' stands for Disarmament, Demobilization and Reintegration. It is an aspect of the Security Sector Reform (SSR) in post-conflict states geared towards de-militarization of society in pursuit of sustainable peace and stability (Molloy, 2015). 


\subsection{Meaning of DDR}

DDR refers to the process of demilitarizing official and unofficial armed groups by controlling and reducing the possession and use of arms, by disbanding non-state armed groups and right-sizing state security services and by assisting former combatants to reintegrate into civilian life (Ball \& Goor, 2006). More lucidly, (Carames \& Sanz, 2009) define DDR as:

a process that targets a determinate number of combatants, whether as individuals or groups, belonging to the Armed Forces or armed opposition groups, in order to disarm, demilitarize and reintegrate these persons into civilian life, the Armed Forces or the Police.

It follows from the foregoing definitions that DDR is a wartime or post-conflict phenomenon that can target both state and non-state military actors (ex-combatants), with a view of either reintegrating them into regular state military services, or demilitarizing and re-civilianizing them for onward reintegration into the civil society.

\subsection{Components of DDR}

DDR can be viewed as a five-stage process that involves weapons surrender, assembly (collection), discharge, short-to-medium reinsertion, and longer term reintegration (Ball \& Goor, 2006). The main components of the process include disarmament, demobilization, reinsertion and reintegration. The aforementioned aspects of DDR have been operationally defined by the (United Nations Office on Drugs Crime, 2005) as contained in Table 1.

\begin{tabular}{l|l}
\multicolumn{2}{c}{ Table-1. Operational Definitions of Components of DDR. } \\
\hline Component & Definition \\
\hline Disarmament & $\begin{array}{l}\text { Collection, documentation, control and disposal of small arms, ammunition, explosives and } \\
\text { light and heavy weapons of combatants and often also of the civilian population; } \\
\text { development of responsible arms management programmes. }\end{array}$ \\
\hline Demobilization & $\begin{array}{l}\text { Formal and controlled discharge of active combatants from Armed Forces or other armed } \\
\text { groups; processing of individual combatants in temporary centers, massing of troops in } \\
\text { designated camps for the purposes of the above }\end{array}$ \\
\hline Reinsertion & $\begin{array}{l}\text { Short term transnational assistance given to ex-combatants in the form of material and/or } \\
\text { financial offering(s) to meet their personal and family needs in the interim. }\end{array}$ \\
\hline Reintegration & $\begin{array}{l}\text { Process by which ex-combatants acquire civilian status and gain sustainable employment } \\
\text { and income; it is a social and economic process with an open time frame, primarily taking } \\
\text { place in communities at the local level as part of the general national development drive in } \\
\text { the post-conflict era. }\end{array}$ \\
\hline Source: United Nations Office on Drugs Crime (2005).
\end{tabular}

Table-2. Patterns of DDR based on Country-specific Contexts.

\begin{tabular}{|c|c|}
\hline Country & Pattern \\
\hline Afghanistan & Unilateral disarmament, demobilisation, reintegration of Armed Forces in wartime \\
\hline Angola & $\begin{array}{l}\text { Bilateral demobilisation of Armed Forces and armed opposition groups for security sector reform in post- } \\
\text { war conflicts }\end{array}$ \\
\hline Burundi & Multilateral DDR with restructuring to the Armed Forces in a post-war context \\
\hline Chad & $\begin{array}{l}\text { Bilateral demobilisation of militias and Armed Forces containing child soldiers in a context of regional } \\
\text { insecurity }\end{array}$ \\
\hline Colombia & Unilateral demobilization of paramilitaries in a war context \\
\hline Cote D'Ivoire & $\begin{array}{l}\text { Bilateral demobilisation of Armed Forces and armed opposition groups and security sector reform in a } \\
\text { post-cold war context. }\end{array}$ \\
\hline $\begin{array}{l}\text { Central } \\
\text { Republic }\end{array}$ & Bilateral demobilisation of armed opposition groups in post-war conflict \\
\hline DR Congo & Bilateral demobilisation of militias for security sector reform in post war context \\
\hline Eritrea & $\begin{array}{l}\text { Mass demobilisation, reinsertion and reintegration of Armed Forces and security sector reform in a post } \\
\text { war context. }\end{array}$ \\
\hline Indonesia & $\begin{array}{l}\text { Disarmament and reintegration of the Free Aceh Movement armed opposition group and redeployment of } \\
\text { state security forces in Aceh. }\end{array}$ \\
\hline Liberia & $\begin{array}{l}\text { Multilateral and mass disarmament, demobilization, rehabilitation and reintegration of a wide variety of } \\
\text { combatant groups, with special attention paid to child soldiers and a redistribution of political power. }\end{array}$ \\
\hline Nepal & $\begin{array}{l}\text { Cantonment and Identification of the People's Liberation Army (PLA) with a process of discussion for } \\
\text { military and civilian reintegration in a context of political transition. }\end{array}$ \\
\hline Rwanda & Demobilization of armed opposition groups with security sector reforms \\
\hline Sudan & $\begin{array}{l}\text { Disarmament, demobilisation and reintegration occurring jointly with integration of armed groups and } \\
\text { the building of the Armed Forces. }\end{array}$ \\
\hline Uganda & $\begin{array}{l}\text { Disarmament, demobilisation and reinsertion programming targeting a variety of armed opposition } \\
\text { groups containing large numbers of women and child soldiers. }\end{array}$ \\
\hline Nigeria & $\begin{array}{l}\text { Disarmament, demobilisation and reintegration of ex-militants in a context of counter-insurgency } \\
\text { programme. }\end{array}$ \\
\hline
\end{tabular}




\subsection{Patterns of DDR}

Based in the peculiarity of the principles and practices of DDR in different states over the years, a number of patterns of DDR can be identifies. Table 2 gives valuable insights in that regard.

\subsection{Target Groups/Beneficiaries of DDR}

The primary target groups of DDR are state and non-state ex-combatants. However, dependants of these ex-combatants as well as the communities where they resettle may benefit from DDR programmes. Table 3 puts the above notion into proper perspective.

Table-3. Target Groups/ Beneficiaries of DDR.

\begin{tabular}{l|l}
\hline Targets/Beneficiaries & Remark(s) \\
\hline Combatants & $\begin{array}{l}\text { Males and females who have participated in combat; support agents to the } \\
\text { combats such as cooks, porters, messengers, sex slaves, abductees. }\end{array}$ \\
\hline Dependants & The spouses, children and other dependants of the combatants \\
\hline Communities & $\begin{array}{l}\text { The communities where ex-combatants resettle may benefit from DDR } \\
\text { programme, especially when they are delivered through community-based } \\
\text { mechanisms, }\end{array}$ \\
\hline
\end{tabular}

\subsection{Principles of DDR}

The two cardinal principles of DDR are amnesty and civil acceptance. Amnesty presupposes that there should be total state pardon for those who have volunteered to disarm and demobilize. There should be a firm assurance for the ex-combatants that they will be re-integrated, not punished (Waldorf, 2009). In other words, the processes and outcome of DDR should be credible and gracious enough to foreclose all possibilities of future criminal prosecution and victimization. The principle of civil acceptance entails that the ex-combatants and their support agents must be freely and unconditionally accepted by the civil society or regular military structures. They should be rest assured of public empathy and trust in the course of their reintegration processes. Most importantly, there should be a sense of assurance that the candidates are not stigmatized. These principles are fundamental to the success of the DDR programme.

\subsection{Significance of DDR}

DDR is strategic to effective resolution of violent conflict. It is also indispensable to sustainable peacebuilding in post-conflict war scenarios. According to Ball and van de Goor:

The process of disarmament, demobilisation and reintegration (DDR) of former combatants plays a critical role in transitions from war to peace. DDR processes have become an integral part of peacekeeping operations and post conflict reconstruction activities. Their success or failure can affect long tern peace building prospects for any post-conflict society (2006: iv).

To what extent is the aforementioned assertion true of Rwanda? This question forms the main concern of the subsequent sections of this paper. But before we delve into this concern, an overview of the Rwandan crisis/ conflict is germane so as to properly situate the discourse.

\section{Overview of the Rwandan Crisis}

The Rwandan crisis stated in 1990 when the Rwandan Patriotic Front (RPF), a Tutsi-dominated exiled rebel movement based in Uganda invaded Rwanda. This dramatic invasion triggered a wave of violence that culminated in a civil war that lasted for four years. The RPF demanded the right to return for all Tutsi refugees as well as political power sharing with the Hutu-dominated Rwandan Government led by Juvenal Habyarimana. Habyarimana's government was authoritarian and unpopular. The government came under a sapping pressure from the international community and domestic opponents to democratise. In response to the rising pro-democracy pressures, the government got reactionary, militarized the Rwandan society, and brutalized the Tutsi civilians (Waldorf, 2009).

The 1992 ceasefire agreement between the RPF and the Rwandan government failed in early 1993, leading to an upsurge of violence in some parts of Rwanda. Peace talk resumed in the second quarter of 1993 , culminating in the Arusha Accords that created a broad-based government that retained Habyarimana in power after a strategic power sharing deal between the government and the oppositions. As part of the peace deal, the RPF was to be integrated into the new national army. Amidst palpable fears of retrenchment, numerous Rwandan army officers and soldiers opposed the peace agreement (Waldorf, 2009).

On April 6, 1994, Habyarimana's plane was shot down by unknown assailants, resulting in his death. This incident informed a tumultuous uprising wherein Hutu extremists seized control of the state and orchestrated massive extermination campaign against the Tutsi. The outcome of this orgy of violence was the notorious Rwandan genocide that led to the death of half a million Tutsi (Pottier, 2002). The genocide ended in 1994 with the military triumph of the RPF and the exile of the Hutu-dominated genocidal forces to Zaire (now DR 
Congo). The forces remobilized at the refugee camps in Zaire and, with the backing of the Mobutu Sese Seko's regime, launched counter-attacks on Rwanda.

Following complaints of political victimization by the Congolese Tutsi, Rwanda led an irredentist attack on Zaire (now DR Congo) in 1996, in coalition with Uganda, Angola and Laurent Desire Kabila's Alliance of Democratic forces for the Liberation of Congo-Zaire (AFDL). This incident led to the toppling of Mobutu in May 1997 and the installing of Kabila as president (Pottier, 2002). Sequel to the backlash of anti-Tutsi disposition by Kabila's government in 1998, Rwanda instigated an anti-Kabila rebellion led by the Congolese Rally for Democracy (RCD). Then again, Rwanda invaded Congo alongside Uganda and Burundi.

In 1999, Rwanda became engrossed in a battle for the control of natural resources in Kisangani and eastern Congo areas. In this regard, it participated in arming, financing and mentoring ethnic militias in the region for the purposes of seizing territory and extracting natural resources (Waldorf, 2009). In the process, it fell out with its erstwhile strategic ally, Uganda. The crisis was addressed by the Lusaka agreement wherein parties agreed to disarm the relevant militias and turn over suspected genocide's culprit to the International Criminal Court (ICC).

Following the assassination of President Kabila in January 2001, Joseph Kabila, his son assumed the presidency. Joseph Kabila exhibited more commitment to the Lusaka agreement and demonstrated favourable disposition to future peace deals. The protracted dialogue hosted by South Africa in 2002 materialized in the resolution by Rwanda and the Kinshasha government to cease hostilities. Consequently, the Rwanda troops pulled out of eastern Congo by October 2002, paving the way for all stakeholder agreement that installed a transitional government in July, 2003. The transition ended in November 2006 with a national election that returned Kabila as president. Since then, Rwanda has been under uneasy stability with reduced military disturbances.

\section{The Rwandan DDR Experience}

DDR in Rwanda had obtained in two dispensations: 1997-2001 and 2001-2008. The first phase (19972001) was focused in the military sector while the second phase (2001-2008) included the ex-armed groups. The Rwandan DDR was anchored by the Rwandan Demobilisation and Reintegration Commission (RDRC) whose targets included to:

i. Demobilise and reintegrate 22000 members of the Rwandan Defence Force (RDF) and 12500 members if the whom 11250 were adults and 1250 are child soldiers from armed groups (AG);

ii. Support reinsertion and reintegration of 13000 settled ex-forces Armies Rwanduises (ex-FAR);

iii. Support the socio-economic reintegration of all stage II ex-combatants and vulnerable excombatants of stage I who remain socio-economically vulnerable;

iv. Facilitate re-allocation of government expenditure from defence to social and economic sectors; and

v. Support the reinsertion of 5600 dependants of members of the ex-armed groups (Rwanda, 2002).

Although RDRC was formed in 1997 as an autonomous government commission, it was not formally and statutorily established until 2002. Box 1 highlights some vital information on the RDRD.

Box-1. The Rwandan Demobilisation and Reintegration Commission (RDRC): Quick Review.

The Rwandan Demobilization and Reintegration Commission (RDRC), was formed in January 1997 as an
autonomous government commission, and was formally established in the year 2002 by a presidential
decree no $37 / 01$ of 09/04/2002.
It is charged with planning and implementing the Rwandan Demobilisation and Reintegration
programme for ex-combatants. The commission is composed of 5 commissioners including the Chairman.
A Technical Secretariat (TS), headed by a Programme Coordinator, assist the Commission to implement
the programme and has five departments namely: Operations, Finance, Human Resources and
Administration, Procurement and Monitoring and Evaluation.
Under the Operation department are 5 Provincial Reintegration Officers (RROS) which support the
reinsertion and reintegration activities of the programme in 30 districts.
Source: www.mifotra.gov.rw/fileadmin/user_upload/chaters?RDRC_PDF (accessed $4 / 4 / 2016)$.

Operationally, DDR work in Rwanda focused on a number of aspirations:

i. Demobilising approximately 36,000 ex-combatants, 20,000 from the old Armed Forces and 16000 from armed groups with support for reintegration into civilian life;

ii. Reinserting ex-FAR members and reducing government military spending by redirecting funds to social and economic projects;

iii. Reintegrating ex-combatants demobilised in a previous phase into social and economic life, in compliance with Arusha agreement;

iv. Providing consistent support for ex-combatants assisting communities with reintegration and promoting confidence measures in government;

v. Ensuring social security and pensions for ex-combatants are given for RDRD assistance (Carames \& Sanz, 2009) 
The Rwandan DDR was based on the principle of self-persuasion: Target groups were entreated and persuaded to identify with the process without any resort to state coercion. However, ensure that the participants were really from the rank and file of the ex-combatants, certain eligibility criteria were set inter alia:

i. The participant/candidate must be of Rwandan nationality;

ii. He/she must prove his status as a combatant;

iii. He/she must prove his affiliation to an armed group;

iv. He/she must show military experience combating with the APR in the DR Congo or Rwanda or;

v. He/she must demonstrate military ability (e.g capacity to use a gun) (Carames \& Sanz, 2009).

The Rwandan DDR was funded by a multilateral arrangement involving the Rwandan government and other international platforms. Table 4 provide useful data in this regard.

Table-4. Funders of the Rwandan DDR.

\begin{tabular}{l|l|l}
\hline Donor/Funder & Million USD & \% \\
\hline World Bank & 32.7 & 48.3 \\
\hline MDTF & 14.4 & 21.3 \\
\hline United Kingdom, DFID & 8.8 & 13.1 \\
\hline Germany, GTZ & 8.6 & 12.7 \\
\hline Government of Rwanda & 2.7 & 4.0 \\
\hline African Union & 0.3 & 0.4 \\
\hline Total & 67.6 & 100 \\
\hline Source: MDRP, Rwandan Fact sheet, cited in (Carames \& Sanz, 2009).
\end{tabular}

Data reflected in Table 4 above point to the fact that the Rwandan DDR was well funded by way of a multilateral intervention. The table also indicate that the Rwandan Government contributed a paltry percentage of the funds (2.7\%). It is to be noted that the information (facts and figures) contained in Table 4 refer to the second phase of DDR implementation in Rwanda (2001-2004). Whereas the Rwandan Government only played a complementary role in generating the baseline funds in this dispensation, it principally bore the funding requirements in the first phase (1997-2001).

The first phase of DDR in Rwanda started in 1997 and ended in 2001. In this dispensation, a total of 18,692 RPA soldiers were demobilised while 15,000 ex-FAR soldiers were reintegrated into RPA (Takeuchi, 2011). This period of DDR implementation in Rwanda was characterized by a number of factors. First, it was military sector-oriented, principally targeting ex-combatants within the sector. Secondly, DDR in this dispensation was marked by limited success arising from budgetary shortfalls. Thirdly, the DDR package was not comprehensive enough to cater for the armed groups and the female soldiers (Waldorf, 2009). The involvement of the Rwandan government in the crisis situation occasioned general donor reluctance towards the Rwandan DDR efforts. Thus, amidst operational limitations arising from funding and logistics, Rwandan DDR endeavours in the first phase became ineffective and challenged. The second phase of DDR in Rwanda (2001-2008) was well programmed and funded. It was also comprehensive in focus, targeting female soldiers, child soldiers, ex-combatants' dependants and armed groups (Waldorf, 2009). It marked a clear departure from the first phase by emphasizing the demobilization of the various armed groups that participated in the Rwandan crisis. Demobilization of RDF soldiers started in April 2002 and terminated in 2006. The formal yardsticks for demobilizing the RDF soldiers included illness, disability and age. Demobilising RDF soldiers received a parting allowance that amounted to thirty percent of his last monthly pay (Waldorf, 2009).

Ex-combatants from armed groups were disarmed in the DRC by the MONUC before their return to Rwanda. To be eligible for demobilization the ex-combatants had to prove that they returned to Rwanda after May 2001; could handle an assault rifle; and belonged to a certain military command structure (Waldorf, 2009). The ex-combatants participating in the DAR programme in phase II were gathered in 'solidarity camps' (ingando) where they were exposed to civic trainings covering aspects of the Rwandan culture, history and heritage, public health, micro-financing, national unity and conciliation, etc. The demobilisation programme was significantly successful, although there was a low rate of demobilisation by ex-armed groups who were still engaged in fighting in the region (Takeuchi, 2011). Table 5 provides useful insights in this regard.

Table-5. Demobilisation in Rwanda (2001-2006): Objectives and Reductions attained.

\begin{tabular}{l|l|l|l}
\hline Category & Number of ex-combatants & Percentage \\
\hline Ex-RDF (Adults) & Objective & Attained & $\%$ \\
\hline Ex-FAR (Adults) & 20,000 & 20,039 & $100 \%$ \\
\hline Ex-Armed Groups (Adults) & 13,000 & 12,969 & $100 \%$ \\
\hline Ex-Armed Groups (Children) & 14,400 & 6,005 & $42 \%$ \\
\hline Total & 1,600 & 644 & $40 \%$ \\
\hline Source: Takeuchi (2011). & 49,000 & 39,657 & \\
\hline
\end{tabular}


In terms of reintegration, DDR in Rwanda was also fairly successful. Participants were given both insertion and reintegration supports. The vulnerable ex-combatants were given some social security grants while ex-combatants were encouraged to form associations for micro-financing. The success narrative of the re-integration has been aptly captured thus. All ex-combatants receive reinsertion support (Basic Needs Kit) when they graduate from ingando (solidarity camp). Reinsertion support consists of approximately US $\$ 100$ and basic household supplies. As of May 2007, 38,846 ex-combatants (including 260 women) had benefited from reinsertion support. 47 All ex-combatants also receive reintegration support consisting of between US $\$ 150$ and US $\$ 2,000$ each according to their rank and affiliation. As of February 2007, 40,068 ex-combatants (including 346 females) had received reintegration support. In addition, all former professional soldiers (exRPA, ex-FAR and ex-RDF) receive a Recognition of Services Allowance, which ranges from $\$ 300$ for privates to $\$ 1,000$ for colonels. This allowance is paid in two instalments: a first instalment of US\$100 is paid one month after the former soldier settles in a community or registers with the RDRC, and the balance is paid two months after this. In addition, the most vulnerable ex-combatants are eligible for a one-time Vulnerability Support Window grant of approximately US\$333. Recipients for this grant are publicly selected by local-level committees comprised of excombatant representatives, administrative officials and the RDRC. The RDRC has also encouraged ex-combatants to form associations and micro-credit projects to improve their economic opportunities (Takeuchi, 2011). There were also breakthroughs in respect of demilitarisation of child soldiers. As pointed out by Takeuchi (2011) child soldiers from different groups have been demobilised and reintegrated in three distinct phases:

i. RPF Child soldiers from 1994 through 1998

ii. Child soldiers who accompanied the ALIR I incursion into Rwanda; and

iii. Child soldiers with armed combatants in Congo.

The child soldiers were made to pass through three month rehabilitation at designated canters after which they were reunited to their families. After joining their families, some of the child-soldiers benefitted from the state facilitated health-care, vocational training and some form of vulnerability-based education support.

\section{Peculiarities and Legacies of the Rwandan Model of DDR}

The Rwandan model of DDR essentially fits into the conventional mode of DDR in the contemporary world. Operationally, however, it has a number of contextual peculiarities that make it stand out. First, it technically excluded the disarmament component of the DDR process (Takeuchi, 2011). In other words, there was no concrete scheme or programme by which it sought to disarm the ex-combatants and/or military dissidents. Secondly, DDR in Rwanda was highly military centred. To be sure, the first phase (1997-2001) led to the demobilisation of 18,692 RPA soldiers and the re-integration of around 15,000 ex-FAR soldiers into the regular national force (Waldorf, 2009). Although, the second phase (2001-2008) vigorously sought to include the various ex-armed groups, it nonetheless faired rather badly in making significant impact in that regard (Takeuchi, 2011). Thirdly, the Gracaca system of transitional justice provided the enabling environment for the success of DDR in Rwanda, particularly in the second phase. One of the important indicators of the success of DDR in Rwanda was the downsizing 80,000 in 2002 to 35,000 in 2008 (Takeuchi, 2011). Thus reduction of the military size by half not only helped in stabilizing and professionalizing the Armed Forces, but also helped in forestalling dissidence within the sector. Fiscally, it reduced the hitherto huge budgetary allocations on military (Waldorf, 2009) enabling their reinvestment on other competitive sectors of the national economy. Furthermore, the Rwandan DDR was inclusive and sensitive to human security. In addition to the cash allowance given to participant at the time of demobilization and reintegration a grant called 'vulnerability support window' was instituted for ex-combatants. There were also assistance packages dedicated to former child soldiers, female ex-combatant, disabled and chronically ill ex-combatants, as well as dependants of the ex-armed groups (Takeuchi, 2011). On the whole, the Rwandan example of DDR can be said to be fairly successful. This is in spite of the perceptible threat of criminal prosecution of ex-combatants who have identified with the process as well as the continued violence orchestrated by recalcitrant armed groups in some parts of the country. As (Waldorf, 2009) puts it:

Post-genocide Rwanda provides a remarkable counter-example, where DDR has largely succeeded despite the ongoing threat of criminal prosecutions. Most of the ex-combatants who fought on the side of the genocidal forces have been demobilised and reintegrated over the last twelve years.

\section{Conclusion and Recommendation}

DDR is a veritable aspect of the contemporary security sector reform (SSR) in conflict torn countries. It also fits into the agenda of state/peace-building in the post-conflict states. Over the years a variety of DDR has been implemented in different parts of the world, with African states taking a lion's share. The Rwandan model of DDR, implemented between 1997 and 2008, represents an instance of a successful DDR programme in Africa. The greatest legacy of the Rwandan DDR was its success in bringing about effective demobilisation and reintegration of many ex-combatants within the domain of formal military sector. Its success in the area of ensuring disarmament, demobilisation and reintegration of the ex-armed groups was vitiated by the dialectics 
of domestic and regional security in the Great Lakes region. In the light of the limited success of the Rwandan DDR efforts, it is therefore recommended that future DDR programmes in Africa should be holistic and pragmatic enough to address the concerns of DDR within the formal military sector as well as frontiers of militia formations. This entails considering DDR not merely as a SSR, but essentially, an effort at state building in conflict and post-conflict situations.

\section{References}

Ball, N., \& Goor, V. D. (2006). Disarmament, demobilisation and reintegration: Mapping issues, dilemmas and guiding principles. Centre for International Policy, Netherlands Institute of International Relations, August.

Banholzer, L. (2004). When do disarmament, demobilisation and reintegration programmes succeed? Paper presented at the Discussion Paper Deutsches Institut fur Entwicklungs Politik

Carames, A., \& Sanz, E. (2009). Analysis of disarmament, demobilisation and reintegration (DDR) programmes in the world during 2008. Bellaterra: School for Culture of Peace, 2009.

Molloy, D. (2015). Disarmament, demobilisation and reintegration (DDR) in offensive operations in the context of violent extremism: What space for human security in new UN policy formulation? IRGR Op Ed, December.

Okoli, A. C. (2015). State building and post-conflict situations in Africa: An overview. Research Paper.

Pottier, J. (2002). Re-imagining Rwanda: Conflict, survival and disinformation in the late twentieth century. Cambridge: University Press.

Rwanda. (2002). Presidential decree (No 37/01 of 09/04/2002) establishing the Rwandan Demobilisation and Reintegration Commission (RDRC). Government of Rwanda.

Social Development Department. (2009). Conflict, crime and violence. No. 119, February.

Takeuchi, S. (2011). Gracaca and DDR: The disputable record of state building in Rwanda. JICA R1 Working Paper, No 32, JICS Research Institute, July.

United Nations Office on Drugs Crime. (2005). 2005 World drug report (Vol. 2): United Nations Publications.

Waldorf, L. (2009). Transitional justice and DDR: The case of Rwanda. International Centre for Transitional Justice.

Appendix-1:

Table-6. The Context of DDR Programmes in 1989-2010: Conflict status, the way in which the conflict ended, the presence of an international peace mission, and whether DDR was followed by lasting peace.

\begin{tabular}{|c|c|c|c|c|c|c|}
\hline & $\begin{array}{l}\text { Start of } \\
\text { DDR }\end{array}$ & $\begin{array}{l}\text { End of } \\
\text { DDR }\end{array}$ & $\begin{array}{l}\text { Status of } \\
\text { conflict when } \\
\text { DDR started }\end{array}$ & $\begin{array}{l}\text { Way in which } \\
\text { conflict ended }\end{array}$ & $\begin{array}{l}\text { International } \\
\text { peace mission? }\end{array}$ & $\begin{array}{lr}\text { DDR followed } \\
\text { by lasting } \\
\text { peace? }\end{array}$ \\
\hline Afghanistan & 2003 & 2005 & Ongoing & $\ldots$ & Yes & No \\
\hline Angola & 1994 & 1996 & Terminated & Peace agreement & No & Yes \\
\hline Angola & 2002 & 2009 & Ongoing & Low activity & Yes & No \\
\hline Bosnia-Herzegovina & 1995 & 2007 & Terminated & Peace agreement & Yes & No \\
\hline Burundi & 2004 & 2008 & Ongoing & Peace agreement & Yes & No \\
\hline Cambodia & 1992 & 1993 & Ongoing & Victory & Yes & Yes \\
\hline Central African Republic & 2004 & 2007 & Terminated & Victory & Yes & No \\
\hline Chad & 2005 & 2010 & Ongoing & Low activity & Yes & $\mathrm{No}$ \\
\hline Colombia & 2003 & 2006 & Ongoing & $\ldots$ & No & Yes \\
\hline Congo-Brazzaville & 2008 & 2009 & Terminated & Ceasefire & No & Yes \\
\hline Democratic Republic of Congo & 2004 & 2012 & Ongoing & Peace agreement & Yes & No \\
\hline El Salvador & 1992 & 1993 & Terminated & Peace agreement & Yes & No \\
\hline Eritrea-Ethiopia I & 1993 & 1997 & Terminated & Peace agreement & No & Yes \\
\hline Eritrea-Ethiopia II & 2002 & 2008 & Terminated & Peace agreement & Yes & No \\
\hline Ethiopia-Eritrea I & 1991 & 1994 & Terminated & Victory & No & Yes \\
\hline Ethiopia-Eritrea II & 2000 & 2007 & Terminated & Peace agreement & Yes & Yes \\
\hline Guatemala & 1996 & 1998 & Terminated & Peace agreement & Yes & Yes \\
\hline Guinea Bissau & 2001 & 2005 & Terminated & Victory & No & Yes \\
\hline Haiti & 1994 & 1996 & Terminated & Victory & Yes & No \\
\hline Indonesia (East Timor) & 1999 & 2001 & Terminated & Peace agreement & Yes & Yes \\
\hline Indonesia (Aceh) & 2005 & 2009 & Terminated & Peace agreement & No & Yes \\
\hline Ivory Coast & 2005 & 2008 & Terminated & Peace agreement & Yes & Yes \\
\hline Liberia & 2003 & 2008 & Terminated & Peace agreement & No & Yes \\
\hline Mali (Azawad) & 1996 & 1997 & Terminated & Low activity & No & No \\
\hline Mozambique & 1992 & 1994 & Terminated & Peace agreement & Yes & No \\
\hline Namibia & 1989 & 1989 & Terminated & Peace agreement & Yes & Yes \\
\hline Nepal & 2007 & 2012 & Terminated & Peace agreement & No & Yes \\
\hline Nicaragua & 1989 & 1992 & Ongoing & Ceasefire & Yes & Yes \\
\hline Niger (Air and Azawad) & 2006 & 2007 & Terminated & Peace agreement & No & Yes \\
\hline Philippines (Mindanao) & 1997 & 2006 & Ongoing & $\ldots$ & No & No \\
\hline Rwanda I & 1997 & 2001 & Terminated & Peace agreement & No & No \\
\hline Rwanda II & 2001 & 2008 & Ongoing & Low activity & No & $\mathrm{No}$ \\
\hline Serbia & 1999 & 2001 & Terminated & Peace agreement & No & Yes \\
\hline Sierra Leone & 1998 & 2004 & Ongoing & Peace agreement & Yes & Yes \\
\hline Somalia & 2003 & 2007 & Terminated & $\ldots$ & No & No \\
\hline Sudan & 2005 & 2012 & Ongoing & $\ldots$ & Yes & No \\
\hline
\end{tabular}




\begin{tabular}{l|l|l|l|l|l|l}
\hline Tajikistan & 1999 & 2003 & Terminated & Victory & Yes & Yes \\
\hline Uganda I & 1992 & 1995 & Ongoing & Low activity & Yes & No \\
\hline Uganda II & 2000 & 2008 & Ongoing & Low activity & No & No \\
\hline UK (Northern Ireland) & 1998 & 2005 & Terminated & Ceasefire & No & 23 \\
\hline Total & & & $\begin{array}{l}26 \\
\text { (terminated)/14 } \\
\text { (ongoing) }\end{array}$ & & Yes & \\
\hline
\end{tabular}

Source: Adapted from Banholzer (2004). When do Disarmament, Demobilization and Reintegration programmes succeed? Bonn: Germany Development Institute.

Appendix-2. Abbreviations.

\begin{tabular}{l|l}
\hline \multicolumn{2}{l}{ Appendix-2. Abbreviations. } \\
\hline RDRC & Rwandan Demobilisation and Reintegration Commission \\
\hline FAR & Forces Democratiques de Liberation du Rwanda \\
\hline AGs & Forces Armees Rwandaises \\
\hline RDF & Armed Groups \\
\hline RPA & Rwandan Defence Force \\
\hline DDR & Rwandan Patriotic Army \\
\hline DRC & Disarmament, Demobilisation and Reintegration \\
\hline UNO & Democratic Republic of Congo \\
\hline RPF & United Nations Organisation \\
\hline
\end{tabular}

